\title{
MICROBIOTA OF VAGINA AND MAMMARY GLANDS SKIN IN THE PREGNANT WOMEN WITH PREECLAMPSIA
}

\author{
V. Ya. Ivankiv, I. M. Malanchyn, N. I. Tkachuk \\ I. HORBACHEVSKY TERNOPIL STATE MEDICAL UNIVERSITY, TERNOPIL, UKRAINE
}

Background. Timely prediction, diagnosis and prevention of complications during the gestational period leading to perinatal loss and maternal mortality are the main tasks of contemporary obstetrics. About 50,000 women die from preeclampsia and eclampsia every year and perinatal mortality ranges from 15 to $25 \%$.

Objective. The aim of the research was to study and analyze the microecology of vagina and mammary glands skin in the pregnant women with underlying preeclampsia.

Methods. The pregnancy examination was conducted at the Ternopil Regional Clinical Perinatal Center "Mother and Child". The research involved 25 pregnant women with preeclampsia (the main group) and 15 healthy women with a physiological course of pregnancy (the control group). Material from the pregnant women was taken out of the skin of mammary glands and mucous membrane of vagina, then it was plated out in the nutrient medium for the cultivation and the microorganisms were defined.

Results. The quantitative composition of a normal microflora of vagina and mammary glands skin in the control group was within the normal range. The quantitative composition of a normal microflora of vagina and mammary glands skin in the pregnant women of the main group decreased, the representatives of opportunistic and pathogenic flora were found.

Conclusions. In the pregnant women with preeclampsia, abnormal microbiocenosis of vagina and breast skin was revealed, the degree of abnormality correlated with the severity of the disease. Our results may provide useful clinical knowledge to a broader understanding of microbiota role in pregnancy complications.

KEY WORDS: preeclampsia; microbiocenosis of mammary glands skin; perinatal mortality.

\section{Introduction}

In the structure of maternal and perinatal morbidity and mortality, preeclampsia is one of the most leading causes. The incidence of preeclampsia in Ukraine ranges from 6 to $16 \%$. Perinatal mortality in preeclampsia is high and, according to various authors ranges from 15 to $25 \%$. Today, preeclampsia is established to be an inability of the adaptive mechanisms of a parent organism to adequately provide the needs of fetal development, manifested by perfusion-diffuse insufficiency in the motherplacenta-fetus of varying degrees of severity $[1,2,3,4,5]$.

Preeclampsia is not an independent disease; it is just a manifestation of a systemic inflammatory response syndrome to oxidative stress, endothelial dysfunction, thrombophilia, metabolic homeostasis, and normal microbiota. In

Corresponding author: Viktoria Ivankiv, I. Horbachevsky Ternopil State Medial University

1 Maydan Voli, Ternopil 46001, Ukraine

phone number +380972340892

e-mailvivankiv@meta.ua the pregnant women with preeclampsia, often a violation of the qualitative and/or quantitative composition of the representatives of normal microflora of the body takes place. This leads to adaptive or irreversible changes in the appropriate microbiological link, which is termed 'dysbiosis' $[6,7,8,9]$.

Physiological colonization is important because normal flora supports immunological homeostasis, suppresses pathogenic microorganisms. The process of formation of microflora of a newborn and the development of its immune system may be disturbed if the expectant mother suffers from pathology of gastrointestinal tract, dysbiosis, has sources of chronic infection, or suffered from preeclampsia during pregnancy. Identifying the beneficial and detrimental microbial components and their roles during pregnancy may have extremely important implications.

According to the literature, there are rare reports on the study of microbiota of mammary gland skin $[15,17]$, so, the aim of our research was to study the microbiota of vagina and 
mammary glands skin in the pregnant women with preeclampsia.

\section{Methods}

The study involved 25 pregnant women with preeclampsia (the main group) and 15 healthy women with a physiological course of pregnancy (the control group). Mild preeclampsia was diagnosed in $15(60 \%)$ of the examined patients, and the severe one was in $10(40 \%)$. Classification of preeclampsia in the pregnant women was conducted in accordance with the Amendment 10 of the ICD (1995), Order of the Ministry of Health of Ukraine dated December 31, 2004 No. 676. Material from the pregnant women was taken out of the skin of mammary glands and the mucous membrane of vagina, then it was plated out in the nutrient medium and the microorganisms were defined.

The examination of the pregnant women was conducted at the Ternopil Regional Municipal Perinatal Center "Mother and Child" in several stages. First, the skin of the mammary glands was rinsed, and the posterior vault of the vagina was smeared from the mucous membrane with sterile swabs pre-moistened in physiological solution. The material was taken by scrolling all the sides of cotton swab. After that, the tampons were placed in sterile tubes and delivered to the laboratory. The time was 20-30 minutes from the time of taking the research material to the crop. The samples were carried out on Petri dishes with sterile media: yolk-salt agar, bloods MPA (for detection of cocci microorganisms), Endo (Enterobacteriaceae), Sabouraud's dextrose agar (fungus of the genus Candida), thioglycollate broth (anaerobic microorganisms). The media was placed in an incubator for 18-48 hours at an optimal temperature. We evaluated the growth of microorganisms in the media after incubation in the incubator (their shape, color, size of the colonies, nature of the surface and edges). Next, smears of certain types of colonies were made, stained with Gram method and examine microscopically.

\section{Results}

As a result of microscopic examination, in 15 women of the control group (pregnant women with a physiological pregnancy course) the following was revealed:

1 ) on the skin of mammary glands: E. coli, Fusobacterium spp., aerobic non-spore-forming gram-positive bacilli, M. roseus, Streptococcus spp., lactose-negative gram negative rods in $6,7 \%$ of the examined patients; Lactobacillus spp., S. haemolyticus in 13,3\%; S. saprophyticus in 20,0\%; Corynebacterium spp. in $26,77 \%$; Clostridium spp., Bacillus spp. in 33,0\%; M. luteus in 40,0\%, Peptostreptococcus spp., S. epidermidis, M. lylae in 47,0\%; Bacteroides spp. in 60,0\% (Fig. 1).

2) in the vaginal smears: S. hominis, Aerobic non spore-forming Gram-Positive Bacillia, $S$. haemolyticus at 6,7\%; Streptobacillus spp.,

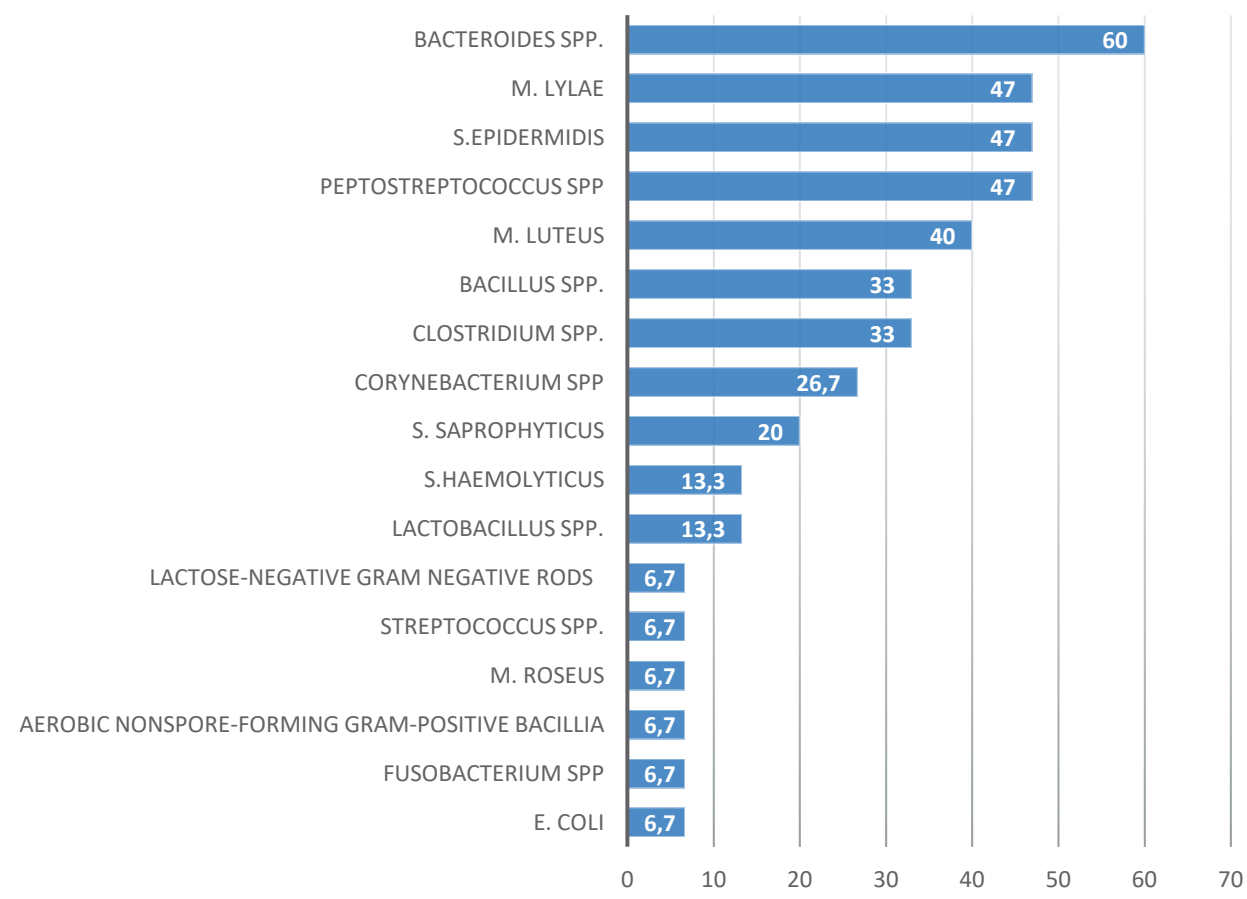

Fig. 1. Colonization of microorganisms on the skin of the mammary glands (control group), \%. 
Streptococcus spp., M. lylae in 13,3\%; Candida spp., E. coli, S. saprophyticus, Lactose-negative gram negative rods in 20,0\%; M. luteus in 33,0\%; Lactobacillus delbrueckii, Corynebacterium spp., S. epidermidis, Bacillus spp. in 40,0\%; Clostridium spp., Bacteroides spp., Enterococcus spp. in 47,0\%; Lactobacillus spp. in $73,3 \%$ of the examined women (Fig. 2).

In 15 pregnant women of the main group with mild preeclampsia:

1) on the skin of mammary glands: Candida spp. in 6,7\%; M. Iylae, $\beta$ - hemolytic streptococcus in 13,3\%; Corynebacterium spp., S. saprophyticus in 20,0\%; S. aureus in 26,7\%; Bacillus spp., S. epidermidis in 33,3\%; M. luteus, S. haemolyticus in $87,0 \%$ of the examined women (Fig. 3).

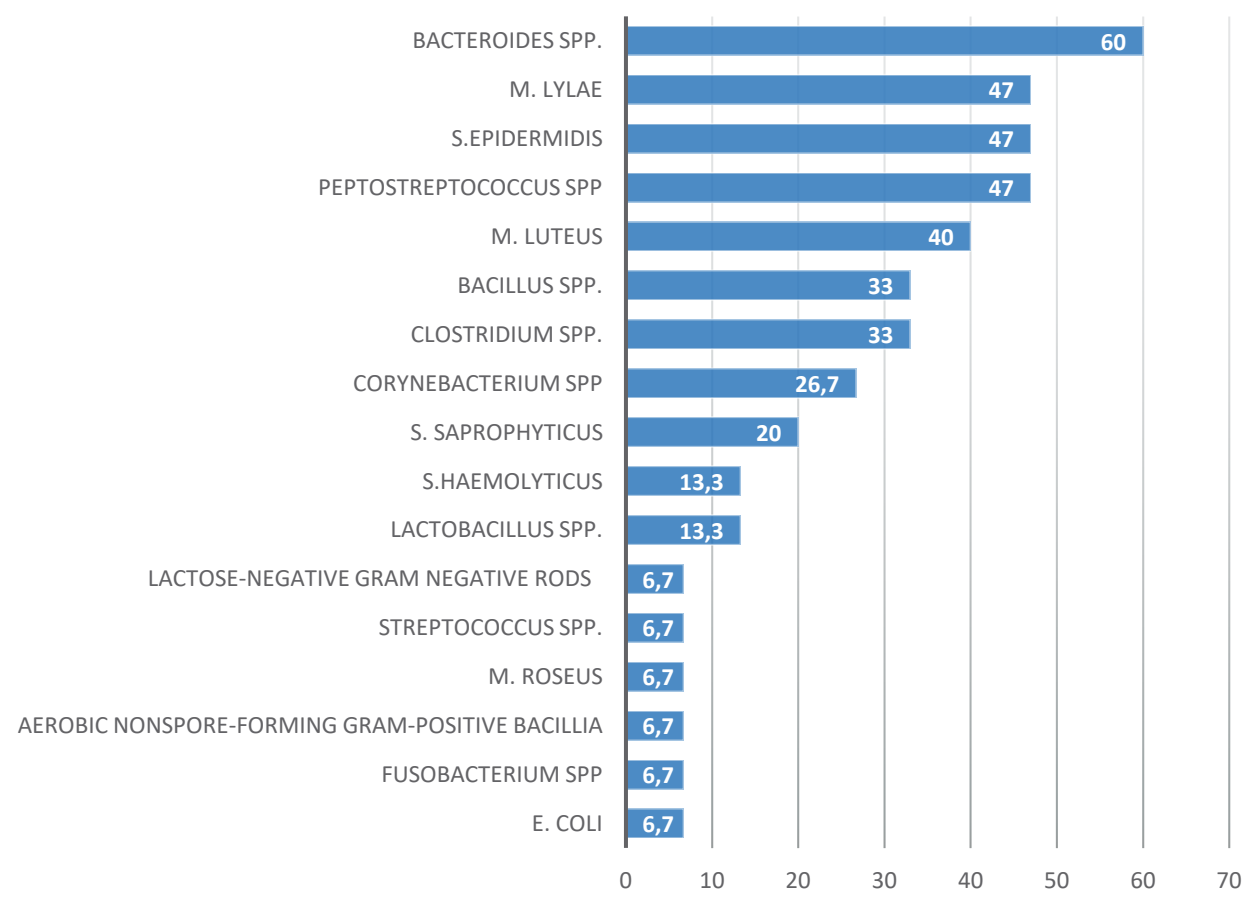

Fig. 2. Colonization by microorganisms of the vaginal mucosa (control group), $\%$.

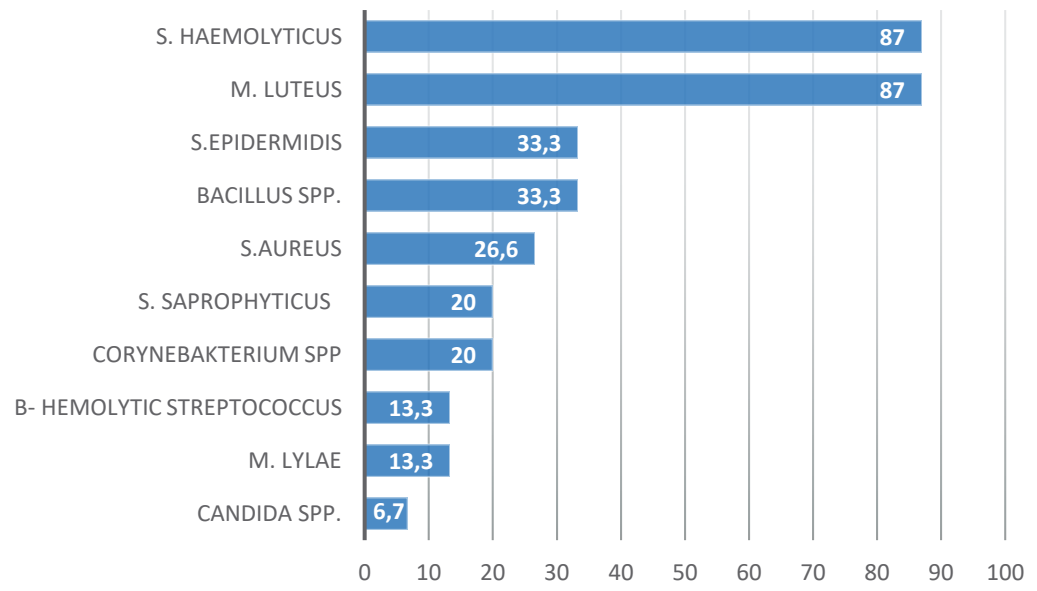

Fig. 3. Colonization of microorganisms on the skin of the mammary glands (the main group, a mild preeclampsia), \%.

46 V. Ya. Ivankiv et al.

ISSN 2413-6077. IJMMR 2018 Vol. 4 Issue 2 


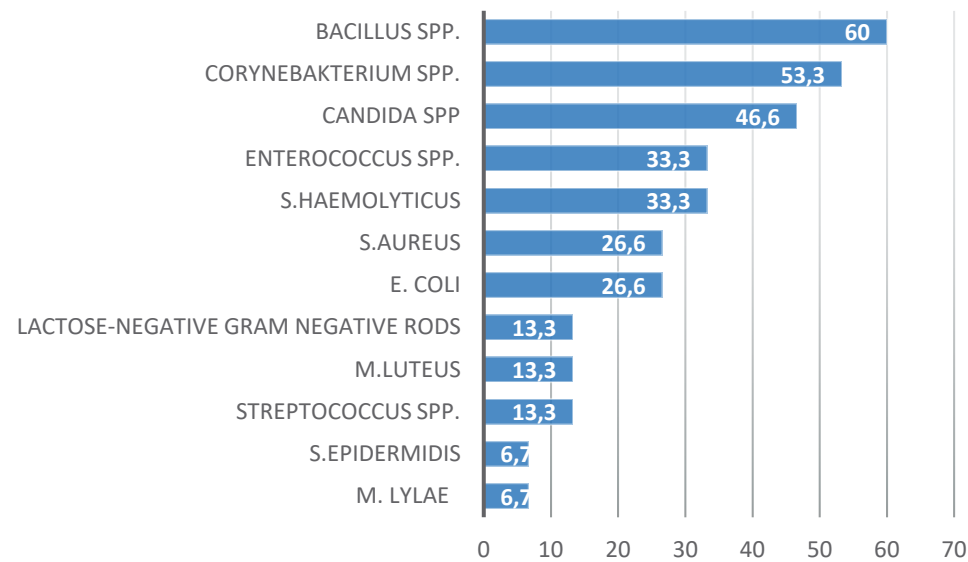

Fig. 4. Colonization by microorganisms of the vaginal mucosa (the main group, a mild preeclampsia), \%.

negative rods, E. coli in 26,6\%; Candida spp., S. aureus in 33,3\%; Enterococcus spp., Bacillus spp. in $46,6 \%$, S. haemolyticus in 73,3\% (Fig. 6).

\section{Discussion}

Since the pathogenesis of preeclampsia is not fully studied, it is practically impossible to prevent its development. However, it is estab- lished that in the presence of some risk factors, development of preeclampsia is more frequent. At present, there is no 'gold standard' in the diagnosis of preeclampsia, and maternal and infant mortality from this pathology is still high, therefore, there is a need for further search for new pathogenesis as well as development of screening diagnostic methods.

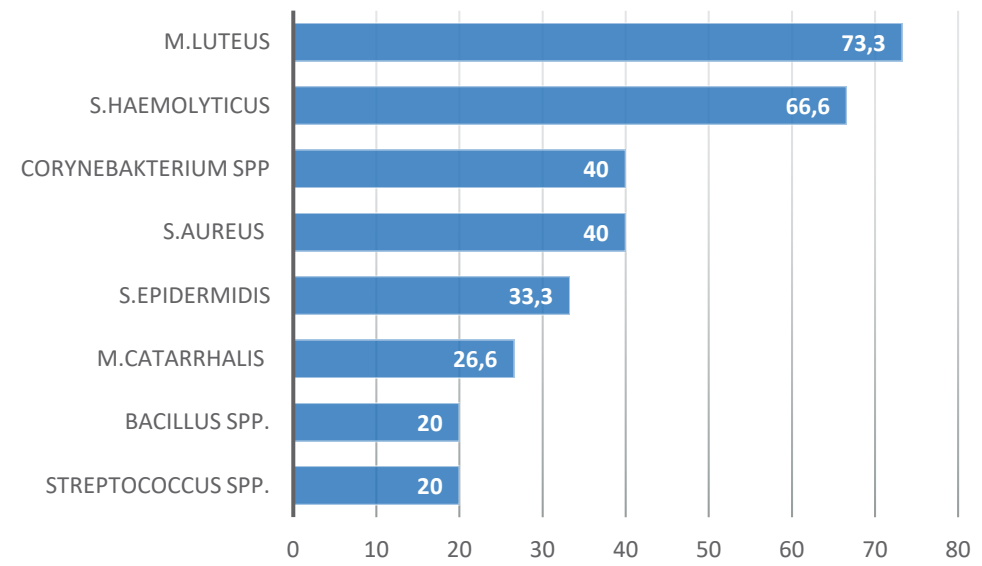

Fig. 5. Colonization of microorganisms on the skin of the mammary glands (the main group, severe preeclampsia), \%.

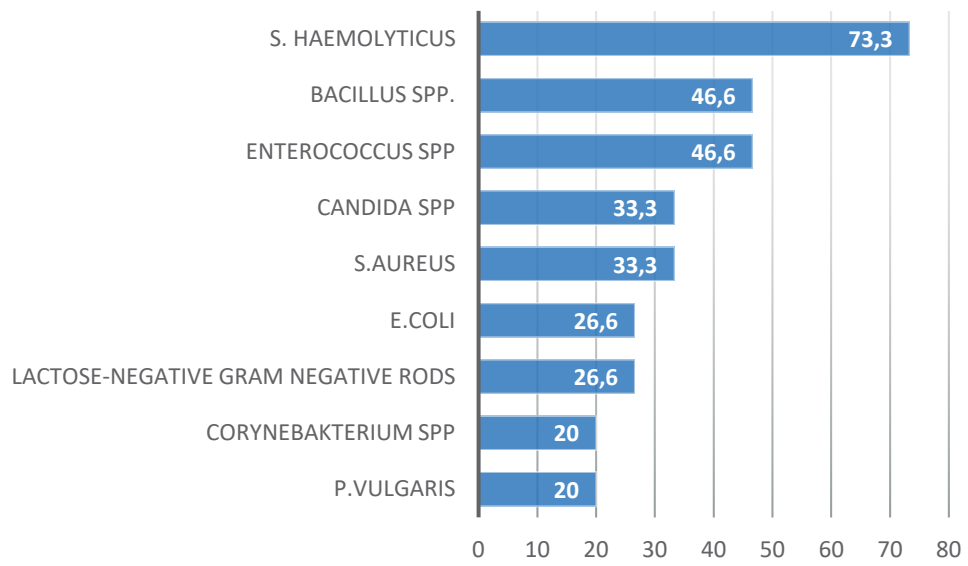

Fig. 6. Colonization by microorganisms of the vaginal mucosa (the main group, severe preeclampsia), \%. 
The further health care of a woman with preeclampsia is a topical issue. Previously, it was established that the problem of preeclampsia disappears after all. However, according to current literature, this condition has a significant impact on the woman's health and is manifested by the increased risk of development of arterial hypertension, cardiovascular diseases and cerebral circulation disorders in the future $[10,11,12]$. Recent Scandinavian studies have argued that pregnant women, who suffered from preeclampsia before the $37^{\text {th }}$ week of gestation, have an 8-time increase of a risk of cardiovascular death over the next 13 years.

Therefore, it is advisable to recommend to women, who suffered from preeclampsia, an annual examination to evaluate cardiovascular risk as well as keeping a healthy lifestyle in order to avoid long-term consequences of late gestosis $[13,16]$.

The search for new pathogenesis of preeclampsia would reduce the level of maternal and perinatal mortality and improve the quality of life of pregnant women and childbirth.

\section{Conclusions}

The representatives of normal microflora: saprophytic Gram-positive and Gram-negative microorganisms, found on the skin of mammary glands of the control group of women, coincide with the literature data. In the pregnant women with mild preeclampsia, there is an increase in the number of $S$. haemolyticus from $13 \%$ to $87 \%$, the presence of the representatives of pathogenic flora: S. aureus (in $27 \%$ of the examined). In the patients with moderate preeclampsia, the number of S. aureus (40\%). Depending on the composition of the microflora of a pregnant woman (normocenosis or dysbiosis) and the functional state of mother-placenta-fetus system the microflora of newborns is developed, and their immune system is established.

In the study of microbiocenoses of vaginal mucosa in the examined pregnant women with preeclampsia, in comparison with the control group, a significant decrease in lactic acid bacteria (Lactobacillus delbrueckii, Lactobacillus spp.) was evidenced as well as the increase in the incidence of coccal flora (S. haemolyticus, S. aureus, $\beta$-hemolytic streptococcus). All this evidence the presence of one of the main signs of dysbiosis - a decrease in the frequency of lactic acid bacteria.

Dysbiosis of the skin of mammary glands is found in $87 \%$ of the examined of the main group, mucous membrane of vagina - in $73 \%$.

In the pregnant women with preeclampsia, abnormal microbiocenosis of vagina and breast skin was revealed; the degree of changes correlated with the severity of preeclampsia. The analysis of individual variants of microbiota in the examined main group proved that destabilization of a microbial ecosystem takes place before childbirth, which, in our opinion, is associated with changes in the immune system during pregnancy and with certain obstetric pathologies such as preeclampsia. The most unfavorable combination is preeclampsia together with dysbiosis, where significant dysbiotic disorders of both vagina and mammary glands skin with the phenomena of colonization of conditionally pathogenic and transient flora in high diagnostic concentrations are present. It is necessary to make correction of dysbiotic disorders in the pregnant women, and in the future, to maintain normal microflora of the newborns that reduces the number of chronic diseases and slows down the aging process.

\title{
МІКРОФЛОРА ПІХВИ ТА ШКІРИ МОЛОЧНИХ ЗАЛОЗ У ВАГІТНИХ ЖІНОК 3 ПРЕЕКЛАМПСІЄЮ
}

\author{
В. Я. Іванків, І. М. Маланчин, Н. І. Ткачук \\ ТЕРНОПІЛЬСЬКИЙ ДЕРЖАВНИЙ МЕДИЧНИЙ УНІВЕРСИТЕТ IМЕНІ І. Я. ГОРБАЧЕВСЬКОГО, \\ ТЕРНОПІЛЬ, УКРАЇНА
}

Вступ. Своєчасне прогнозування, діагностика та профілактика ускладнень вагітності, які призводять до перинатальних втрат і материнської смертності $є$ важливим завданням сучасного акушерства. Близько 50 тисяч жінок щорічно помирають від прееклампсії та еклампсії, а перинатальна смертність становить від 15 до 25\%.

Мета дослідження полягала у вивченні та аналізі мікробіоценозу піхви і шкіри молочних залоз у вагітних з прееклампсією. 
Методи дослідження. У дослідження включено 25 вагітних з прееклампсією (основна група) ma 15 здорових жінок з фізіологічним перебігом вагітності (контрольна група) (Тернопільський обласний клінічний перинатальний центр “Мати і дитина"). У обстежуваних жінок брали мазки зі шкіри молочних залоз і слизової оболонки піхви, матеріал висівали в живильні середовища для культивування.

Результати. У вагітних основної групи кількісний склад нормальної мікрофлори піхви і шкіри молочних залоз був порушений, виявлено представників опортуністичних бактерій і патогенної флори. Ступінь аномалій мікробіоценозу корелює з тяжкістю клінічних проявів.

Висновки. Наші результати дослідження дозволять розширити розуміння ролі і зв'язку змін мікрофлори та ускладнень вагітності.

КЛЮЧОВІ СЛОВА: прееклампсія; мікробіоценоз шкіри молочних залоз; перинатальна смертність.

\section{References}

1. Order of the Ministry of Health of Ukraine № 676: About the approval of clinical protocols for obstetric and gynecological care; 31-12-2004. Available at http://old.moz.gov.ua/ua/portal/ dn_20041231_676.html

2. Acker LV, Warshavskyi BYa, Elganinova SA. Indicators of oxidative and antioxidant stress in pregnant women with gestosis. Obstetrics and Gynecology 2013;4:17-20.

3. Mellina IN. A combination of preeclampsia in pregnant women with hypertension: warning possible and necessary. Medical Aspects of Women's Health 2011;4(44):5-13.

4. Saveleva GM, Shalina RI. Gestosis in modern obstetrics. International Medical Journal 2015;1:50-53.

5. Shyphman EM. Preeclampsia, eclampsia, NELLP syndrome. Petrozavodsk. Intel-Tech;2012: 38-129.

6. Magee LA, Hellewa M, Moutquin JM, von Dadelszen P. Diagnosis, Evaluation, and Management of the Hypertensive Disorders of Pregnancy. Journal of Obstetrics and Gynaecology Canada 2016;3:1-48.

7. National Clinical Guideline Center. Hypertension in pregnancy. The management of hypertensive disorders during pregnancy. National Institute for Health and Clinical Excellence. NICE clinical guideline; 2010:288.

8. Brown MA. Preeclampsia: a lifelong disorder. Medical Journal 2013;4(179):181-182.

9. Definitions of Preeclampsia - updated 2014. Available at http://www.obgyn.net/.
10. Odent M. Hypothesis: Preeclampsia as a Maternal-Fetal Conflict. MedGenMed 2011; 5:20-21.

11. Preventing pre-eclampsia - are dietary factors the key? - updated 2014. Available at http:// www.ncbi.nlm.nih.gov/pubmed

12. The pre-eclampsia community guideline (PRECOG): how to screen for and detect onset of pre-eclampsia in the community - updated 2015. Available at https://www.ncbi.nlm.nih.gov/ pubmed/15760998.

13. Roberts et al. Preventing and treating eclamptic seizures. BMJ 2012; 325:609-610.

14. International Classification of Diseases 10 views - updated 1995. Available at http://mkh10.com. ua/

15. Malanchyn IM. Condition of microbiocenosis of the skin of the mammary glands, intestines and vagina in pregnant women with preeclampsia. Actual Problems of Pediatrics, Obstetrics and Gynecology 2010;1:140-2.

16. Malanchyn IM, Koptyukh VI, Franchuk OA. Remote consequences postponed preeclampsia. Actual questions of pediatrics, obstetrics and gynecology 2014;2:160-162.

17. Ivankiv VYa, Malanchyn IM, Tkachuk NI. Ecological features of microbiocenosis of the skin of mammary glands and vagina in pregnant women with threat of preterm labor. International Journal of Medicine and Medical Research 2017;2:51-53. 